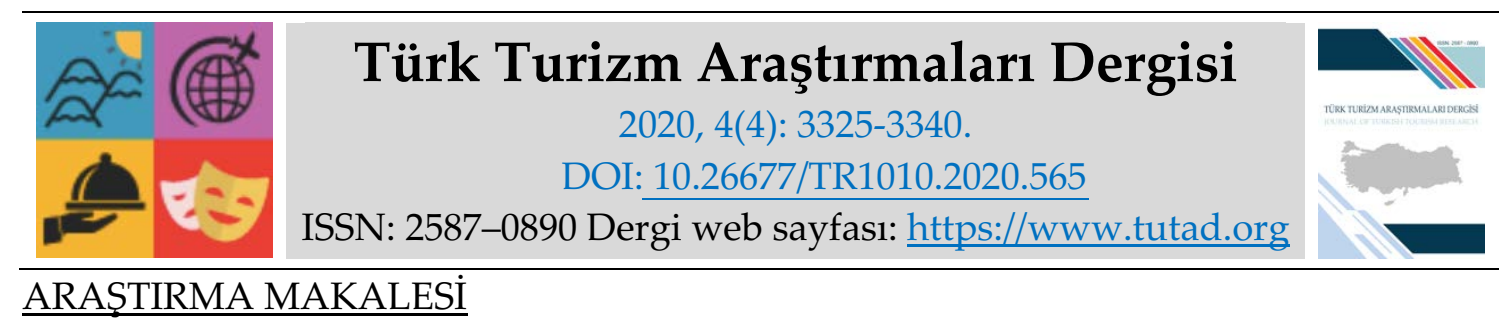

\title{
Demografik Faktörlerin Kriz Yönetim Becerilerine Etkisi: Turist Rehberleri Üzerine Bir Araştırma
}

Dr. Öğr. Üyesi Tolga Fahri ÇAKMAK, Zonguldak Bülent Ecevit Üniversitesi, Karadeniz Ereğli Turizm Fakültesi, Zonguldak, e-posta: tolgafahricakmak@gmail.com

ORCID: https://orcid.org/0000-0002-7952-1102

Prof. Dr. Füsun İstanbullu DİNÇER, İstanbul Üniversitesi, İktisat Fakültesi, İstanbul, e-posta: istanbul@istanbul.edu.tr

ORCID: https://orcid.org/0000-0001-9446-5519

$\ddot{O ̈ z}$

Krizlere verilen tepkiler sadece işletme ya da bireylerin önceden yaptıkları kriz hazırlıkları kapsamında gerçekleşmemekte, aynı zamanda bireylerin cinsiyetleri, eğitim seviyeleri ve iş deneyimleri gibi değişkenler etrafında şekillenebilmektedir. Bu durum da krizlere olan hazırlık gerekliliklerinde hesaba katılması gereken ek parametreler olarak ortaya çıkmaktadır. Çalışmanın amacı, turist rehberlerinin demografik faktörlerinin kriz yönetiminde karar alma sürecini nasıl etkilediğini bulmaktır. Çalışma 386 adet turist rehberinden anket aracılığ 1 ile toplanan veriler çerçevesinde gerçekleştirilmiştir. Araştırmanın demografik bilgiler kapsamında yapılan değerlendirmeleri kısmında öncelikle kadın turist rehberlerinin, krizlerin pek çok evresinde erkek meslektaşlarına göre daha başarılı bir kriz yönetimi sergilediği görülmüştür. Meslekteki deneyim süresine göre yapılan incelemede de deneyim süresinin krizlerden etkilenme oranını doğrudan etkilediği ve bireyin deneyimi arttıkça krizi yönetebilme becerilerinin daha da yükseldiği fark edilmiştir. Son olarak turist rehberlerinin eğitim seviyesinin kriz yönetimi üzerinde anlamlı bir etkisinin olmadığı gözlenmiştir.

* Bu çalışma “Turizm Endüstrisinde Kriz Yönetimi: Turist Rehberleri Üzerine Bir Alan Araştırması" isimli doktora tez çalışmasından türetilmiştir.

Anahtar Kelimeler: Kriz Yönetimi, Turist Rehberi, Turizm.

Makale Gönderme Tarihi: 03.06.2020

Makale Kabul Tarihi: 07.10.2020

\section{Önerilen Atıf:}

Çakmak, T. F. ve Dinçer, F. İ. (2020). Demografik Faktörlerin Kriz Yönetim Becerilerine Etkisi: Turist Rehberleri Üzerine Bir Araştırma, Türk Turizm Araştırmaları Dergisi, 4(4): 3325-3340.

(C) 2020 Türk Turizm Araştırmaları Dergisi. 


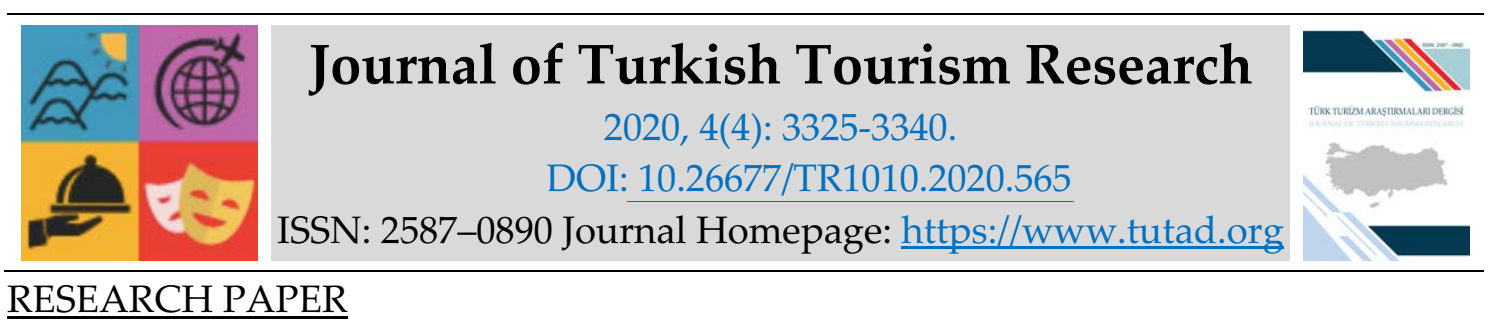

\title{
The Effect of Demographic Factors on Crisis Management Skills: A Research on Tourist Guides
}

Assistant Prof. Dr. Tolga Fahri ÇAKMAK, Zonguldak Bülent Ecevit University, Karadeniz Ereğli Faculty of Tourism, Zonguldak, e-mail: tolgafahricakmak@gmail.com ORCID: https://orcid.org/0000-0002-7952-1102

Prof. Dr. Füsun İstanbullu DİNÇER, İstanbul University, Faculty of Economics, İstanbul, e-mail: istanbul@istanbul.edu.tr

ORCID: https://orcid.org/0000-0001-9446-5519

\begin{abstract}
The responses to crises are not only realized within the scope of crisis preparations made by the business or individuals, but can also be shaped around variables such as individuals' gender, education levels and work experiences. This situation emerges as additional parameters to be taken into account in preparation requirements for crises. The aim of this study is to find out how the demographic factors of tourist guides affect the decision-making process in crisis management. The study was carried out within the framework of data collected from 386 tourist guides via questionnaire. Whether the average of the questions asked in the questionnaires is equal or not is examined with Hotelling T square. Cronbach's Alpha statistics were preferred as a measure of reliability. Normal distribution test was done in Past software, Shapiro-Wilk, JarqueBera, Monte Carlo approach and Anderson-Darlik normality tests were applied. In the evaluations of the demographic information of the research, it was seen that the female tourist guides showed a more successful crisis management than their male counterparts in many stages of the crisis. In the examination made according to the duration of experience in the profession, it has been noticed that the duration of experience directly affects the rate of being affected by the crisis, and as the experience of the individual increases, their ability to manage the crisis increases even more. Finally, it has been observed that the education level of tourist guides has no significant effect on crisis management.
\end{abstract}

Keywords: Crisis Management, Tour Guide, Tourism.

Received: 03.06.2020

Accepted: 07.10.2020

Suggested Citation:

Çakmak, T. F. and Dinçer, F. İ. (2020). The Effect of Demographic Factors on Crisis Management Skills: A Research on Tourist Guides, Journal of Turkish Tourism Research, 4(4): 3325-3340.

(C) 2020 Türk Turizm Araştırmaları Dergisi. 


\section{Gíriş}

Küreselleşmenin bir getirisi olarak krizler, eskiye oranla çok daha zor mücadele edilen, çok daha yıkıcı olaylar haline gelmişlerdir. Uluslararası ilişkilerin karmaşık yapısının yanı sıra dünyanın jeolojik dengesindeki bozulmalar ve salgın hastalıklar da krizlere daha fazla yol açan sebepler sunmaktadır. Bu doğrultuda gerçekleşen krizler ise sadece ülkeleri ya da örgütleri değil bu örgütleri var eden insan kaynağını da ciddi manada etkilemektedir (Çakmak, 2019a).

Gerçekleşen bu krizler artık süre olarak çok daha uzun zamanları kapsayabilmektedir. Dolayısı ile krize hazırlık sürecinden kriz sonu değerlendirmelerine kadar kriz yönetiminin her bir adımı gelecekte gerçekleşmesi muhtemel başka krizlere hazırlıklı olmak adına büyük önem arz etmektedir. Bu değerlendirmeleri yapmayan ülkeler makro boyutta ekonomik tehlikeler ile karş1 karşıya kalırken, bireyler ya da işletmeler rekabet açısından oldukça zarar görebilmekte, ticari faaliyetleri bitme noktasina gelebilmektedir.

Turizm endüstrisi de krizlerden en çok zarar gören alanlardan biridir. Bu endüstrisi kendi içerisinde seyahat, yeme -içme, ulaştırma, konaklama gibi pek çok alt sektöre ayrılmakta, her bir sektör ise dış çevre ile olabildiğince yakın ilişkiler kurmaktadır. Doğrudan ve dolaylı olarak pek çok sektörü de etkileyen turizm endüstrisi kapsayıcı yapısı sebebi ile aynı şekilde bu sektörlerde gerçekleşen sorunlardan da yoğun zarar görebilmektedir.

Turist rehberleri de turizm endüstrisinde önemli bir iş gücü ve insan kaynağı pozisyonundadır. 1618 sayılı yasa gereği, turist rehberi olmaksızın herhangi bir turun organize edilmesi mümkün değildir. Turist rehberlerinin endüstri içerisinde bu kadar faal olmasına karşın bu meslek grubu ile ilgili kriz yönetimi hususunda çok kısıtlı ya da dolaylı yoldan yayınlara rastlanmaktadır. Turist rehberliği alan yazınında ağırlıklı olarak turist rehberlerinin sahada yaşadıkları sorunların işlendiği gözlenmiştir (Çakmak, 2019b; Çetin ve Kızılırmak, 2012; Karacaoğlu ve Sert, 2018; Yenipınar vd., 2014). Doğrudan kriz yönetimi ve turist rehberliği mesleğini ele alan araştırmaların bu kapsamda sınırlı olduğu, yapılmış çalışmaların ise turist rehberliği öğrencileri merkezli olduğu gözlenmektedir. Bu çalışmalarda turist rehberliği öğrencilerinin krizlere karşı tutumları (Kaya vd: 2020) ve kariyer planlamasındaki etkileri (Yetgin vd., 2018) ele alınmıştır.

$\mathrm{Bu}$ çalışmanın amacı, turist rehberlerinin demografik faktörlerinin kriz yönetim becerileri üzerindeki etkisinin ölçülmesidir. Çalışma verileri anket aracıllğı ile toplam 386 adet turist rehberinden elde edilmiştir. Alan yazınında turist rehberleri konusunda kriz yönetim becerilerini ölçen başka bir çalışmaya rastlanmaması ve krizlerin her geçen gün daha yoğun şekilde tüm dünya ölçeğinde yaşanması sebebi ile çalışma önem arz etmekte olup, turist rehberleri sorunlarını ele alan çalışmalardan bu noktada ayrılmaktadır.

\section{KAVRAMSAL ÇERÇEVE \\ Kriz ve Kriz Yönetimi}

Kriz sözcügü etimolojik köken olarak Latince "krinein", Grekçe "krisis" köklerine dayandırılmaktadır ve bu sözcüklerde temelde karar verme noktasını işaret eden bir ayrılık anlamını taşmaktadır (Örnek ve Aydın, 2008). Krizler, yapılan pek çok çalışmada, çalışmanın ait olduğu bilim dalı ile de alakalı olarak farklı tanımlanan bir kavram olarak karşımıza çıksa da (Çelikkan, 2012; Kongar, 2012; Saruhan ve Yıldız, 2013; Thom, 2001) özünde bir "belirsizlik" halini de beraberinde getirdiği görülmektedir. Öte yandan kavramın sürekli bir değişkenlik içerisinde olması, yani her krizin kendi içerisinde farklı bir karakteristiğe sahip olması kriz olgusunu anlama hususunda da bir sorun teşkil etmektedir. Buradan hareketle bakıldığında kriz kavramı kendi içerisinde de ayrıca bir krizi betimler durumdadır (Öztürk, 2011). Faulkner (2001) krizi adeta bir test olarak tanımlamakta ve bunun organizasyonun ani sorunlar ile başa çıkma 
yeteneğini ölçtügüünü belirtmektedir. Pearson vd., (1997) işletmenin ismine, marka değerine gölge düşürecek nitelikte olan, çalışanların ve toplumun sağlık ve güvenliğini tehlikeye düşüren olaylar olarak tanımlar.

Günümüzde ise krizler, işletmeleri ve bireyleri, verilen kararların doğruluğu konusunda emin olunmayan belirsiz süreçlere sokmaktadır. Bu noktada krizlerin en önemli ortak özelliklerinden biri de belirsizliktir. Bu belirsizlik örgütlerin de çalışanların da yönelimi konusunda çelişkili bir ortam meydana getirir (Tüz, 2008) Etkin bir kriz ile mücadele planı olmayan işletmeler bu süreçte yok olma tehlikesi başta olmak üzere ciddi tehlikeler atlatırken aynı şekilde bireylerde hayatlarında çok zor süreçler yaşamaktadır. Krizlerin ani ve beklenmedik şekilde meydana gelmeleri, krizlerin etkilediği alanın da daha geniş bir ölçeğe yayılmasına sebebiyet verebilmektedir. Bu durum alandaki tüm aktörlere bir tehdit teşkil eder (Tekin ve Zerenler, 2005).

Kriz yönetimi özünde, kriz gerçekleşmeden yapılması gereken bir hazırlık durumunu ifade etmektedir. Kriz başladıktan sonra yapılacak planlar ve eylemler ancak krizin etkisini azaltmaya yönelik eylemlerdir (Kuklan, 1988). Coombs (2006) kriz yönetimini organizasyonun kritik bir süreci olarak tanımlar. Bu sürecin başarısızlığı durumunda hem ortakların hem örgütün hem de çalışanların olumsuz olarak etkilenmesi kaçınılmazdır. Spillan (2003) ise kriz yönetimini krizlerin verdikleri zararı minimize etmeye çalışan ve durumun kontrol altına alınmaya odaklanıldığı bir süreç olduğunu belirtir.

Kriz yönetimi her ne kadar krizler başlamadan önce alınan önemler manasına gelmesi gerekse de gerçek hayatta çoğu zaman krizleri meydana gelmeden engellemek olası değildir, öte yandan bu düşünce tarzı örgüt içi ve örgüt çevresi ile ilgili organizasyon hataları merkezli krizlerde daha da ön plana çıkmaktadır. Fakat doğal afetler ya da pandemi - salgın krizleri gibi olağan üstü ve küresel ölçekli krizlerin önceden tahmini her zaman mümkün olmayabilmekte bu sebeple krizler öncesinde alınan önlemler her zaman yeterli gelmeyebilmektedir. Dolayısıyla kriz yönetimi alan yazınını incelediğimizde krizleri kriz öncesi, kriz anı ve kriz sonrası olarak üç alt başlığa indirgeyerek incelendiği gözlenmektedir. Kriz öncesi yönetim kriz sinyallerinin alındığı, buna göre çevre analizlerinin gerçekleştirilerek krize ilk hazırlıkların gerçekleştiği dönemdir (Tutari 2000; Dinçer, 2013). Kriz anı yönetimi, kriz boyutlarının belirlenerek, bir kriz planının oluşturulduğu bu plana göre insan kaynakları hususunda gerekli ayarlamaların yapıldığı bir süreçtir. Kriz anı yönetiminde temel amaç, kriz sebebi ile meydana gelmesi olası zararın sınırlandırılması ya da azaltılmasına yönelik girişimlerde bulunup krizin örgüt içerisinde yayılmasını engellemektir (Çakmak, 2019). Son aşama olan kriz sonrası aşama ise krizler tamamlandıktan sonra yeni planlama, yeni önlem ve normalleşme süreçlerinin düzenlendiği dönemdir. Okumuş (2003) krizlerden sonra işletmelerin izleyebileceği iki farklı yol olduğunu savunur. İlki, krizlerin tahmin edilenden daha uzun sürmesi sonucu işletme üzerindeki olumsuz etkilerin artmaya devam etmesi ve bunun yeni krizleri tetiklemesidir. Bu durum işletmenin kapanması ya da el değiştirmesi durumuna sebep olur. İkinci yol ise pozitif yönlü olup doğru kararlar sonucu işletmenin krizden sıyrılarak geleceğe güvenle bakabildiği süreçtir.

\section{Turizm'de Kriz Yönetimi}

Turizm endüstrisinin küresel ölçekte hizmet veren geniş yapısı ile direkt ve dolaylı olarak pek çok farklı sektörden hizmet kullanıyor durumda olması, endüstrinin yaşanan her türlü krizden olumsuz etkilenmesine neden olmaktadır (Küçükaltan ve Çiftçi, 2016). Öte yandan günümüzde küresel ölçekli kimi krizler doğrudan ülkelerin turizm endüstrisine zarar verme odaklı bir hal 
aldığı da görülmektedir. Sönmez ve Graefe (1998) uluslararası arenada terörizm faaliyetlerinin ve eylemlerinin 1970'li yıllarda başlayıp ilerleyen on yıllık süre zarfında zirveye çıktığını bildirir. Özellikle 1990lı yıllar ile birlikte eylemlerin turizm endüstrisine yoğunlaştığına da dikkat çekilmektedir. Literatürde turizm ve terörizm ilişkisine odaklanmış pek çok yayın da bulunmaktadır. Bu yayınların özellikle turistlerin neden teröristler için bir hedef haline geldiği, terörist eylemlerin turizm bölgelerindeki talebe etkisi ve turizmde ulaşım şekillerine etkisi konularına odaklandığı görünmektedir (Arana ve Leon, 2008; Drakos ve Kutan, 2003; Korstanje ve Clayton, 2012; Pizam ve Smith, 2000; Richter, 1983; Sönmez vd., 1999; Vivero, 2008). Turistik bölgelerde yaşanan hırsızlık, yaralama, saldırı, tecavüz gibi pek çok suç unsuru (Lind ve Lind, 1986; Pizam, 1999), siyasal krizler temelli sorunlar, (Fletcher ve Morakabati, 2008; Seddighi vd., 2002), doğal afetler (Küçükaltan, 2012; Ritchie ve Campiranon, 2014) gibi etmenler de ulusal ve uluslararası çapta krizlere neden oalrak turizm endüstrisine uzun ve kısa vadede ciddi zararlar vermektedir.

Kriz yönetimi alan yazınını turizm özelinde incelediğimizde pek çok çalışma karşımıza çlkmaktadır (Çiftçi, 2015; Kılıçdere, 2017; Stafford, 2002; Smeral, 2009; Şahin, 2010). Bu çalışmalarda ise konuların ağırlıklı olarak turistik hizmet üreten işletmeler merkezli olduğu ya da makro ölçekli politikalar üretme noktasında uluslararası ilişkileri gözeten konuların çalışıldığı dikkat çekmektedir. Yine bu çalışmaların büyük çoğunluğunun ortak bir yönü de işletme sahipleri ve üst düzey yöneticiler üzerinden araştırmanın yürütülmesi sayılabilir (Aşık, 2016; Kılıçdere, 2017; Sönmez vd., 1999; Sönmez ve Graefe, 1998). Araştırmacılar genelde işletmelerin bir bütün olarak krizlere nasıl hazırlandığı ve ekiplerini oluşturulduğuna odaklanmış, bununla beraber krizlerin yabancı turistleri uğrattığı zararlar sebebi ile meydana gelen uluslararası krizleri ele almışlardır (Akıncı, 2010; Arana ve Leon, 2008).

\section{Demografik Faktörler Kriz Yönetimine Etkisi ve Turizm}

Kriz yönetimi konusunda yapılmış çalışmalarda katılımcıların demografik özellikleri ile kriz yönetim becerilerinin liderlik vasfı kapsamında değerlendirildiği de görülmektedir (Maya, 2014; Ulutaş, 2010; Soysal vd., 2011). Bu çalışmalarda, insan kaynă̆ı konumundaki personelin çalışmayı yapan araştırmacılar tarafından belirlenmiş kimi demografik özellikleri üzerinden krizlere verdikleri tepkiler araştırılmıştır.

Konuyu turizm açısından ele aldığımızda, ilgili alan yazınında bu konu üzerine bir çalışmaya rastlanmamış olup, turist rehberliğinin sadece liderlik kapsamında değerlendirildiği (Acar, 2014; Akoğlan Kozak, 2017; Güzel ve Köroğlu, 2014; Karamustafa ve Çeşmeci, 2006; Türkmen, 2017; Wong ve Lee, 2012) liderlik süreci içerisinde kriz yönetiminin nasıl gerçekleştiğinin incelenmediği görülmüştür. Bu çalışmalarda rehberlerin liderlik sürecinde yaşadıkları sorunları nasıl çözdüğüne değinilse de bunlar birer kriz düşüncesi ile değerlendirilmemiştir.

Krizi yöneten kişilerin demografik özellerine göre yapılmış diğer alanlardaki araştırmalar, farklı alanlarda farklı sonuçlar vermiştir. Ulutaş (2010), eğitimcilerin kriz yönetimi ve dönüşümcü liderlik vasıfları üzerine yaptığı çalışmada cinsiyetler arasında herhangi bir farklılık gözlemlemezken, Soysal vd., (2011) KOBİ üst düzey yöneticileri üzerine yaptıkları çalışmada, kadınların kriz anlarında erkeklere göre daha az rekabetçi, risklerden kaçınan daha edilgen bir rolde olduğunu gözlemlemiştir. Aynı çalı̧̧mada eğitim - kıdem (çalışma süresi) faktörünün arttıkça kriz yönetimi konusunda daha doğru kararların alındığı krizlerden kaçınmaya yönelik daha etkili adımların atıldığı belirtilmiştir. Aynı durum yaş konusunda da gözlenmiştir. Maya (2014) kamu ilkokullarındaki yöneticilerin kriz tepkilerini araştırdığı çalışmasında cinsiyet 
açısından Ulutaş (2010) ile aynı sonuçlara ulaşırken yaş ve deneyim konusunda Soysal vd., (2011) ile aynı sonuçlara ulaşmıştır.

Demografik faktörlerin kriz yönetim becerileri üzerine yapılan bu yayınlarda özellikle; cinsiyet, eğitim seviyesi ve meslekte bulunma sürelerinin etkin şekilde araştırmalara konu olduğu gözlenmiştir.

\section{ARAŞTIRMANIN AMACI ve YÖNTEMI}

$\mathrm{Bu}$ araştırmanın amacı turist rehberlerinin cinsiyet, eğitim durumu ve meslekte fiili olarak geçirdikleri sürelerin krizleri yönetebilme becerileri üzerine etkisinin olup olmadığının öğrenilmesidir. Belirlenen bu kategoriler aynı konuda farklı alanlarda yapılmış çalışmaların kategorik alanları baz alınarak seçilmiştir. Çalışma turist rehberlerinin demografik faktörlerinin kriz yönetimi üzerindeki etkilerini incelemesi bakımından tümden gelimci bir yaklaşım izlemektedir.

Veri toplama tekniği olarak anketlerin kullanıldığı araştırmada, oluşturulan anketin ana hatları, literatür taraması sonucu şekillenmiştir. Anket çalışmasının ilk kısmı olan kriz ölçeği Aksu ve Deveci (2009)'nin oluşturduğu ve geçerli sonuçlar aldığı kriz yönetimi becerileri ölçeğinden faydalanılarak turizm ve turist rehberlerine uyarlanmıştır.

İnceleme kapsamında önce rehberlerin kriz yönetimine yönelik verdikleri cevapların normallik değerleri hesaplanmış ve normal dağılımın gözlenmiştir. Devamında ise belirli demografik faktörler ile kriz öncesi, kriz anı, kriz sonrası etkileri Mann-Whitney U, Kruskal-Wallis ve Bonneforoni, testleri aracılığı ile araştırılmıştır.

\section{KAPSAM ve SINIRLILIKLARI}

Araştırmanın evrenini Kültür ve Turizm Bakanlığı tarafından verilmiş rehberlik ruhsatnamesine sahip, bulunduğu bölgedeki turist rehberliği odasına kayıtlı turist rehberleri oluşturmaktadır. Turist Rehberleri birliğinden alınan turist rehberleri istatistikleri doğrultusunda araştırmanın gerçekleştirildiği 2017 yılında toplam 10283 adet turist rehberi bulunmaktadır. Araştırma evreni de bu rakam doğrultusunda 10283 olarak belirlenmiştir.

Anketler rehber odaları aracıllğı ile rehberlere mail yolu ile gönderilmiştir. Bu amaçla bütün turist rehberleri odaları ile iletişime geçilmiştir. Çalışma kapsamında 15.01.2017-30.06.2017 tarihleri arasında anket doldurma çalışmaları yapılmış ve toplamda 412 adet doldurulan anket sayısına ulaşılmıştır. Anketler incelemelerinde, doldurulan anketlerin 26 tanesi analize uygun olmayacak şekilde eksik ya da hatalı doldurulduğu tespit edilerek analiz listesinden çıkartılmıştır. Çıkartılan anketler sonunda toplamda 386 adet anket analiz için kullanılmıştır.

Yazıcıŏglu ve Erdoğan, (2004) evren büyüklüğü ve örnekleme hatası oranı listesi ne göre büyüklügü 10.000 kişi olan bir evrende 0.005 örnekleme hatası oranı için en az 370 adet örneklem gerekmektedir. Araştırma kapsamında belirlenmiş olan evren kümesinin toplamda 10283 olması ve 386 adet katılımcı ile gerçekleşen çalışma gerekli veri miktarını ulaşmış olarak kabul edilmiştir. Araştırmanın kısıtlılığı anketlerin uygulandığ 6 aylık dönem ile sınırlı olmakla beraber elde edilen verilerin güvenilirliği anketi dolduran turist rehberlerinin ankete verdikleri samimi cevaplar ile sinırlı olmasıdır. 


\section{BULGULAR}

Çalışma kapsamında 386 adet turist rehberine anket çalışması uygulanmıştır. Tablo 1'de çalışmaya katılan anketlerin demografik bilgileri bulunmaktadır.

Tablo 1. Turist Rehberlerinin Özelliklerinin Frekans Dağılımı

\begin{tabular}{|c|c|c|c|c|c|c|c|}
\hline Değişken & Özellik & $\mathbf{N}$ & $\%$ & Değişken & Özellik & $\mathbf{N}$ & $\%$ \\
\hline \multirow[t]{2}{*}{ Cinsiyet } & Kadın & 236 & 61,1 & \multirow{2}{*}{$\begin{array}{l}\text { Ruhsatname } \\
\text { Türü }\end{array}$} & Ülkesel & 378 & 97,9 \\
\hline & Erkek & 150 & 38,9 & & Bölgesel & 8 & 2,1 \\
\hline \multirow{5}{*}{ Yaş } & $18-29$ & 40 & 10,4 & \multirow{9}{*}{$\begin{array}{l}\text { Çalışma } \\
\text { Kartı Sahibi } \\
\text { Olunan Süre }\end{array}$} & 2 yıldan az & 22 & 5,7 \\
\hline & $30-39$ & 122 & 31,6 & & 2- 4 yil & 22 & 5,7 \\
\hline & $40-49$ & 106 & 27,5 & & & & \\
\hline & $50-59$ & 84 & 21,8 & & 5- 7 y1l & 63 & 16,3 \\
\hline & $60+$ & 34 & 8,8 & & & & \\
\hline \multirow{5}{*}{ Eğitim } & Lise & 4 & 1,0 & & 8-10 yıl & 55 & 14,2 \\
\hline & Ön lisans & 61 & 15,8 & & & & \\
\hline & Lisans & 210 & 54,4 & & \multirow[t]{2}{*}{$11+y 1 l$} & \multirow[t]{2}{*}{224} & \multirow[t]{2}{*}{58,0} \\
\hline & $\begin{array}{l}\text { Lisan } \\
\text { üstü }\end{array}$ & 111 & 28,8 & & & & \\
\hline & Toplam & 386 & 100 & & Toplam & 386 & 100 \\
\hline
\end{tabular}

Araştırmada rehberlerin \%61,1'i kadın rehberlerden oluştuğu, \%38,9'u ise erkek rehberlerden oluştuğu belirlenmiştir. Yaşlarının mod sınıfı \%31,6 ile 30-39 yaş aralığı olduğu ortaya çıkmıştır. Çalışmaya katılan turist rehberlerinin eğitim seviyelerinin mod sınıfının $\% 54,4$ ile lisans olduğu belirlenirken lisansüstü eğitime sahip rehberlerin oranı ise $\% 28,8$ olarak belirlenmiştir. Araştırmaya katılan rehberlerin neredeyse hepsi $(\% 97,9)$ ülkesel çalışma ruhsatnamesine sahiptir. Katılımcların sadece \%2,1'lik kısmı bölgesel rehberdir. Kokartlı çalışma yıllarına bakıldığında \%58'inin en az 11 yıldır kokartlı çalıştığı belirlenmiştir.

Çalışmaya öncelikli olarak kadın turist rehberlerinin daha çok ilgi gösterdiği dikkat çekmektedir. $\mathrm{Bu}$ durum kadın turist rehberlerinin turlar esnasında kriz olarak nitelendirilebilecek cinsiyetçi sorunları sıklıkla yaşamalarından kaynaklanabilir. Nitekim alan yazınında da bu konu özellikle ele alınan bir durum olarak karşımıza çıkmaktadır (Arslan ve Şimşek 2018; Demirkol vd., 2004; Yıldırım ve Özbek, 2019). Ankete katılım gösteren turist rehberlerinin büyük bir çoğunluğunun lisans ve lisansüstü seviyede eğitim düzeyinde olması, neredeyse tamamına yakının ülkesel turist rehberi olması ve büyük bir çoğunluğunun meslekte bulunma sürelerinin 8 yıl ve üstü olması çalışmanın güvenilirliğini destekleyen unsurlar olarak değerlendirilebilir.

Araştırmada ölçeklerin güvenirlikleri doğrulayıcı faktör analizi ile birlikte ele alınarak incelenmiştir. Ölçeklerde yer alan ve doğrulanmayan maddeler her iki analizi sonucu uyumlu olacak şekilde ölçekten çıkartılmış ve ölçeklere son halleri verilmiştir. Son hali verilen ölçeklerin güvenirlikleri incelenmiş ve ölçekler güvenilir bulunmuştur. Ölçeklerde, ölçeği bozan herhangi bir ifade olup olmadığı soru bütün korelasyonlara ve ifade silindiğinde ölçeğin güvenilirliğinin arttırıp artırmadığına bakılarak belirlenmiştir. Soru ortalamalarının birbirine eşit olup olmadığ Hotelling T kare ile incelenmiş, güvenirliğin bir ölçüsü olarak Cronbach's Alpha istatistiği tercih edilmiştir. En küçük Cronbach's Alpha istatistiği 0,646 ile krizlerin rehberlerin mesleki yaşamlarına olası etkileri boyutunda (mesleki yeterlilik), en yüksek Cronbach's Alpha istatistiği ise 0,867 ile kriz sonrası ölçeğinde elde edilmiştir. Ölçek ortalamalarına bakıldığında en yüksek ölçek ortalama 4,06 ile kriz sonrası ölçeğinde, en küçük ortalama ise 1,544 krizlerin rehberlerin 
yaşamlarına olan etkisi ölçeğinde elde edilmiştir. Tüm ölçeklerde negatif korelasyona sahip herhangi bir ifade bulunmamış ve ölçekten çıkarıldığında güvenirliği anlamlı şekilde yükselten bir maddeye rastlanmamıştır. Tüm faktörler için Hottelling T Kare değerleri anlamlı bulunmuş ve soru ortalamaları birbirinden farklı bulunmuştur. Elde edilen sonuçlar ve maddelerin betimleyici istatistikleri Tablo 2' de verilmiştir.

Tablo 2. Güvenilirlik Analizi Sonuçları ve Betimleyici Sonuçlar

\begin{tabular}{|c|c|c|c|c|}
\hline Madde & $\begin{array}{l}\text { Ortalam } \\
\text { a }\end{array}$ & Std. Sapma & $\begin{array}{l}\text { Soru } \\
\text { bütün } \\
\text { korelasy } \\
\text { on }\end{array}$ & $\begin{array}{l}\text { Silindiği } \\
\text { nde } \\
\text { Cronbac } \\
\text { h's } \\
\text { Alpha }\end{array}$ \\
\hline \multicolumn{5}{|l|}{ Kriz Öncesi } \\
\hline $\begin{array}{l}\text { Kriz ortaya çımadan önce farklı kaynaklardan gelen kriz } \\
\text { sinyallerini anlayabilirim }\end{array}$ & 3,9922 & ,93556 & 645 & ,808 \\
\hline Kriz yaşanmadan önce kriz senaryoları oluşturabilirim & 3,6658 & ,98018 & ,583 & 821 \\
\hline Turlar için tehlike yaratacak durumu önceden saptarım & 3,9663 & 90391 & 666 & 804 \\
\hline Çevrede meydana gelen krizleri takip ederim & 4,2798 & 83399 & 617 & 814 \\
\hline Krizi meydana getirebilecek her türlü durumu dikkatle incelerim & 4,1580 & 87291 & 683 & ,801 \\
\hline Krizlerin olumsuz etkilerinden korunmaya karşı duyarlıyım & 3,9275 & 95614 &, 520 & ,833 \\
\hline \multicolumn{5}{|l|}{ Alpha= 0,84 Ölçek ort. $=3,998$ Hottelling $T^{2}=147,43$} \\
\hline \multicolumn{5}{|l|}{ Kriz Anı } \\
\hline Kriz anlarında uygulanacak acil eylem planım hazırdır & 3,1373 & 1,19710 &, 525 & ,770 \\
\hline $\begin{array}{l}\text { Oda veya birliğimden kriz yönetimi ile ilgili bilgilendirme } \\
\text { yapması amacı ile eğitim talep ederim }\end{array}$ & 3,0415 & 1,42823 & 633 & ,739 \\
\hline $\begin{array}{l}\text { Kriz kontrol ve risk denetim amacı ile meslektaşlarım ile iletişim } \\
\text { halinde olurum }\end{array}$ & 3,6969 & 1,09963 & ,705 & 714 \\
\hline $\begin{array}{l}\text { Yaşanan krizler ile ilgili diğer rehber arkadaşlarımı haberdar } \\
\text { ederim }\end{array}$ & 4,1321 & 91206 &, 545 & 767 \\
\hline $\begin{array}{l}\text { Tüm rehberleri kapsayacak önlemlerin alınması konusunda etkin } \\
\text { görev alırım (sivil toplum kuruluşlarına katılmak vs.) }\end{array}$ & 3,6321 & 1,12788 &, 504 & 776 \\
\hline \multicolumn{5}{|l|}{ Alpha=0,793 Ölçek ort. $=3,528$ Hottelling $T^{2}=352,287$} \\
\hline \multicolumn{5}{|l|}{ Kriz Sonrası Anı } \\
\hline $\begin{array}{l}\text { Kriz yönetimi sürecinde tüm rehberler ile iş birliği içerisinde } \\
\text { olurum }\end{array}$ & 3,8695 & 1,01232 & 486 & ,861 \\
\hline $\begin{array}{l}\text { Kriz sürecinde verimli çalışmamı önleyen engelleri kriz sonrası } \\
\text { ortadan kaldırırım }\end{array}$ & 4,0261 & 96501 &, 562 & ,856 \\
\hline Oda ve birliğimin kriz süreci eylemlerini değerlendiririm & 3,9896 & 1,01036 &, 504 & ,860 \\
\hline $\begin{array}{l}\text { Kriz süreci ile ilgili tüm turizm sektörünü kapsayan çok yönlü } \\
\text { değerlendirmeler yaparım }\end{array}$ & 4,0653 & 87634 & ,483 & 861 \\
\hline Kriz sonrası yeni hedefler belirlerim & 4,3003 & 81618 &, 538 & ,858 \\
\hline $\begin{array}{l}\text { Gerçekleştirdiğim kriz yönetimini değerlendirir ve eksikliklerimi } \\
\text { belirlerim }\end{array}$ & 4,2141 & 78341 & 607 & 854 \\
\hline $\begin{array}{l}\text { Kriz sonrası rehberlik kariyerimde yeni bir yapılanma çalışması } \\
\text { yaparım }\end{array}$ & 4,0548 & 90062 & 615 & ,852 \\
\hline Kriz sonrası sektörün güçlü ve zayıf yönlerini görebilirim & 4,3107 & ,82504 &, 503 & ,860 \\
\hline Krizle mücadelede etkin yöntemler geliştiririm & 3,7650 & ,99060 & 613 & 852 \\
\hline $\begin{array}{l}\text { Yaşanan krizleri firsata çevirerek mesleki alandaki boşlukları } \\
\text { analiz eder ona göre bir plan geliştiririm }\end{array}$ & 3,6658 & 1,06739 & ,559 & ,856 \\
\hline $\begin{array}{l}\text { Yaşanan krizlere göre eğitimime ve kendimi geliştirmeme yön } \\
\text { veririm }\end{array}$ & 4,1854 & 92640 & ,566 & ,856 \\
\hline $\begin{array}{l}\text { Kriz dönemi edindiğim yeni beceri ve davranışları kriz } \\
\text { sonrasında mesleki hayatıma dahil ederim }\end{array}$ & 4,2533 & 83515 & 601 & ,854 \\
\hline
\end{tabular}


Kriz yönetiminin turist rehberler boyutunda araştırıldığı bu çalışmada, turist rehberlerinin kriz öncesi, kriz anı ve kriz sonrası döneme ait davranışlarının, rehberlerin mesleki yaşamlarına olası etkilerinin, rehberlerin çeşitli kategorik özelliklerine göre farklılık gösterip göstermediği araştırılmıştır. Farklılıkların belirlenebilmesi için her boyut kendi içinde toplanmış ve her boyuttaki madde sayısına bölünmüştür. Böylelikle puanlar 1 ile 5 arasında sıkıştırılmış ve ortalama puanların ölçek yorumlanması sağlanmıştır. Ayrıca her bir rehberin her bir boyuttaki ortalama puanı o rehberin ölçeğe (boyuta) yaklaşımını ifade edecektir.

Rehberlerin kriz yönetimine yönelik puanları arasında farklılıklar araştırılmadan önce puanların normal dağılım gösterip göstermediği araştırılmıştır. Normal dağılım testi Past hazır yazılımda yaptırılmış olup Shapiro-Wilk, Jarque-Bera, Monte Carlo yaklaşımı ve Anderson-Darlik normallik testlerine göre tüm puanlar normal dağılım göstermemektedir. Normallik testleri sonuçları Tablo 3'de verilmiştir. Rehberlerin çeşitli kategorik özelliklerine göre farklılıklar parametrik olmayan istatistiksel yöntemlerle incelenecektir.

Tablo 3. Kriz Yönetim Boyutları Normallik Testi Sonuçları

\begin{tabular}{|l|l|l|l|}
\hline & Kriz Öncesi & Kriz Anı & Kriz Sonrasi \\
\hline $\mathbf{N}$ & 386 & 386 & 386 \\
\hline Shapiro-Wilk W & 0,8944 & 0,9734 & 0,9348 \\
\hline $\mathbf{p}$ (normal) & $1,101 \mathrm{E}-15$ & $1,628 \mathrm{E}-06$ & $5,816 \mathrm{E}-12$ \\
\hline Jarque - Bera JB & 211,8 & 13,81 & 96,32 \\
\hline p (normal) & $9,998 \mathrm{E}-47$ & 0,001005 & $1,213 \mathrm{E}-21$ \\
\hline Anderson-Darling A & 9,876 & 2,503 & 5,874 \\
\hline p (normal) & $6,591 \mathrm{E}-24$ & $2,482 \mathrm{E}-06$ & $1,777 \mathrm{E}-14$ \\
\hline
\end{tabular}

\section{Cinsiyete Göre Kriz Yönetimi}

Rehberlerin kriz yönetimine yönelik puanlarının cinsiyete göre farklılık gösterip göstermediği Mann-Whitney U testi ile araştırılmış ve kriz anı ile kriz sonrası puanlarının cinsiyete göre istatistiksel açıdan anlamlı bir farklılık gösterdiği belirlenmiştir. Cinsiyete göre kriz yönetimi boyutları farklılık testleri Tablo 4 'de verilmiştir.

Tablo 4. Cinsiyete Göre Kriz Yönetimi Boyutları Farklılık Test

\begin{tabular}{|l|l|l|l|l|l|l|}
\hline Boyut & Cinsiyet & $\mathbf{N}$ & Ortalama & Std. sapma & $\mathbf{z}$ & $\mathbf{p}$ \\
\hline Kriz & Kadın & 236 & 4,0678 &, 62244 & & \\
Öncesi & Erkek & 150 & 3,9541 &, 71468 & $-1,760$ &, 078 \\
\hline Kriz & Kadın & 236 & 3,6547 &, 84437 & & \\
\cline { 2 - 6 } Anı & Erkek & 150 & 3,4475 &, 86528 & $-2,119$ &, 034 \\
\hline Kriz & Kadın & 236 & 4,1756 &, 50245 & & \\
\hline \multirow{2}{*}{ Sonras1 } & Erkek & 150 & 3,9863 &, 62310 & $-2,827$ &, 005 \\
\hline
\end{tabular}


Mann-Whitney U testine göre; Rehberlerin cinsiyete göre kriz öncesini yönetebilme puanları arasında istatistiksel açıdan anlamlı bir farklılık bulunmamış $(Z=-1,76 \mathrm{P}=0,078)$, cinsiyete göre kriz anını yönetebilme puanları arasında istatistiksel açıdan anlamlı bir farklılık belirlenmiştir. Belirlenen bu farklılığa göre kadın rehberlerin kriz anı puanları erkek rehberlerden daha yüksek olduğu belirlenmiştir $(\mathrm{Z}=-2,119 \mathrm{P}=0,034)$.

Rehberlerin cinsiyete göre kriz sonrası krizi yönetebilme puanları arasında istatistiksel açıdan anlamlı bir farklılık belirlenmiştir. Belirlenen bu farklılığa göre kadın rehberlerin kriz sonrası krizi yönetebilme puanları erkek rehberlerden daha yüksek olduğu belirlenmiştir $(Z=-2,827$ $\mathrm{P}=0,005)$.

\section{Eğitim Durumuna Göre Kriz Yönetimi}

Rehberlerin kriz yönetimine yönelik puanlarının eğitime göre farklılık gösterip göstermediği Kruskal-Wallis testi ile araştırılmıştır. Ancak lise mezunu 4 rehber bulunduğundan örneklem yeterli görülmemiş ve analizden çıkarılmıştır. Elde edilen sonuçlar Tablo 5 'de verilmiştir.

Tablo 5. Eğitim Durumuna Göre Kriz Yönetim Puanları Farklılık Testi

\begin{tabular}{|c|c|c|c|c|c|c|}
\hline Boyutlar & Eğitim & $\mathbf{N}$ & Ortalama & $\begin{array}{l}\text { Std. } \\
\text { Sapma }\end{array}$ & $\chi^{2}$ & $\mathbf{P}$ \\
\hline \multirow{4}{*}{$\begin{array}{l}\text { Kriz } \\
\text { Öncesi }\end{array}$} & Ön lisans & 61 & 4,0137 & 60881 & \multirow[t]{4}{*}{3,912} & \multirow[t]{4}{*}{ 141 } \\
\hline & Lisans & 210 & 3,9698 & 63868 & & \\
\hline & Lisansüstü & 111 & 4,0270 & 79726 & & \\
\hline & Toplam & 382 & 3,9935 & 68290 & & \\
\hline \multirow{4}{*}{$\begin{array}{l}\text { Kriz } \\
\text { Anı }\end{array}$} & Ön lisans & 61 & 3,4492 & ,91043 & \multirow[t]{4}{*}{2,380} & \multirow[t]{4}{*}{,304 } \\
\hline & Lisans & 210 & 3,4943 & 85687 & & \\
\hline & Lisansüstü & 111 & 3,6180 & ,84834 & & \\
\hline & Toplam & 382 & 3,5230 & 86315 & & \\
\hline \multirow{4}{*}{$\begin{array}{l}\text { Kriz } \\
\text { Sonrası }\end{array}$} & Ön lisans & 61 & 4,1039 & ,59094 & \multirow[t]{4}{*}{2,012} & \multirow[t]{4}{*}{,366 } \\
\hline & Lisans & 210 & 4,0234 & ,58184 & & \\
\hline & Lisansüstü & 111 & 4,0961 & ,59591 & & \\
\hline & Toplam & 382 & 4,0574 &, 58706 & & \\
\hline
\end{tabular}

Lise mezunu dört rehber örneklemden çıkarıldıktan sonra yapılan analize göre rehberlerin eğitim durumuna göre kriz yönetimine yönelik puanları arasında istatistiksel açıdan anlamlı bir farklılık belirlenmemiştir $(P>0,05)$.

\section{Çalışma Kartına Sahip Olunan Süreye Göre Kriz Yönetimi}

Rehberlerin krizi yönetebilme puanlarının çalışma kartına sahip olunan süreye göre farklılık gösterip göstermediği Kruskal-Wallis testi ile araştırılmıştır. Kruskal-Wallis testine göre 
rehberlerin rehberlik kokartlı çalışma yılına göre kriz öncesini yönetebilme boyutunda istatistiksel açıdan anlamlı bir farklılık belirlenmiştir $(\chi 2=11,293 \mathrm{P}=0,023)$. Farklılığın hangi gruplar arasında olduğunu belirlemek için Bonferroni çoklu karşılaştırma testine başvurulmuştur. Elde edilen sonuçlar Tablo 6'de verilmiştir.

Tablo 6: Çalışma Kartına Sahip Olunan Süreye Göre Krizi Yönetebilme Puanları Farklılık Testi

\begin{tabular}{|c|c|c|c|c|c|c|}
\hline Boyutlar & $\begin{array}{l}\text { Kokartlı } \\
\text { Çalışma } \\
\text { Süresi }\end{array}$ & $\mathbf{N}$ & Ortalama & Std. Sapma & $\chi^{2}$ & $\mathbf{P}$ \\
\hline \multirow{6}{*}{$\begin{array}{l}\text { Kriz } \\
\text { Öncesi }\end{array}$} & 2 yıldan az & 22 & 3,6136 & 77218 & \multirow[t]{6}{*}{11,293} & \multirow[t]{6}{*}{,023 } \\
\hline & 2-4 y1l & 22 & 3,8864 & 65139 & & \\
\hline & 5-7 yıl & 63 & 4,1323 & ,48652 & & \\
\hline & 8-10 yil & 55 & 3,8848 & 76233 & & \\
\hline & $11+\mathrm{y} 1 \mathrm{l}$ & 224 & 4,0372 & 68862 & & \\
\hline & Toplam & 386 & 3,9983 & 68175 & & \\
\hline \multirow{6}{*}{$\begin{array}{l}\text { Kriz } \\
\text { Anı }\end{array}$} & 2 yıldan az & 22 & 3,3545 & 90907 & \multirow[t]{6}{*}{2,672} & \multirow[t]{6}{*}{ 614 } \\
\hline & $2-4$ yıl & 22 & 3,7091 & 75272 & & \\
\hline & 5-7 yıl & 63 & 3,6317 & ,81850 & & \\
\hline & 8-10 yıl & 55 & 3,5200 & 88744 & & \\
\hline & $11+y 1 l$ & 224 & 3,5000 & ,87455 & & \\
\hline & Toplam & 386 & 3,5280 & ,86207 & & \\
\hline \multirow{6}{*}{$\begin{array}{l}\text { Kriz } \\
\text { Sonrası }\end{array}$} & 2 yıldan az & 22 & 3,8485 & 71900 & \multirow[t]{6}{*}{4,196} & \multirow[t]{6}{*}{,380 } \\
\hline & 2-4 yıl & 22 & 4,1515 & 60128 & & \\
\hline & $5-7$ yıl & 63 & 4,1601 & ,48251 & & \\
\hline & 8-10 y1l & 55 & 4,0622 & ,54034 & & \\
\hline & $11+\mathrm{y} 1 \mathrm{l}$ & 224 & 4,0428 & 60502 & & \\
\hline & Toplam & 386 & 4,0598 & ,58586 & & \\
\hline
\end{tabular}

Tablo 6' da sonuçları verilen Bonferroni testine göre;

Kokartlı çalışma yılı 2 yıldan az olan rehberler ile kokartlı çalışma yılın 11 yıl ve üzeri olan rehberlerin kriz öncesi krizi yönetebilme puanları arasında istatistiksel açıdan anlamlı bir farklılık belirlenmiştir. Belirlenen bu farklılığa göre 11 yıl ve üzeri kokartlı çalışma yılına sahip olan rehberlerin kriz öncesi krizi yönetebilme puanları kokartlı çalışma yılı 2 yıldan daha az olanlardan daha yüksek bulunmuştur $(\mathrm{P}=0,045)$.

Kokartlı çalışma yılı 2 yıldan az olan rehberler ile kokartlı çalışma yılın 5-7 yıl olan rehberlerin kriz öncesi krizi yönetebilme puanları arasında istatistiksel açıdan anlamlı bir farklılık 
belirlenmiştir. Belirlenen bu farklılığa göre 5-7 yıl kokartlı çalışma yılına sahip olan rehberlerin kriz öncesi krizi yönetebilme puanları kokartlı çalışma yılı 2 yıldan daha az olanlardan daha yüksek bulunmuştur $(\mathrm{P}=0,040)$.

\section{SONUÇ ve DEĞERLENDİRME}

Küresel ölçekte krizlerin her alanda giderek artış göstermesi ve sürekli fakat farklı nitelikteki krizler ile ülke, örgüt ve bireylerin makro ölçekten mikro ölçeğe karşı karşıya kalması durumu, krizler ile başarılı mücadele etme hususunda alınacak önlemleri de etkilemektedir. İnsanlar artık eskiye oranla daha fazla kriz ile mücadele etmekte, sadece kendi yaşam çevresinde olan değil tüm dünyada gerçekleşen krizler ile gerçek zamanlı yüzleşmektedir. Bir diğer değişle küreselleşme insanların hayatları boyunca karşılaştı̆̆ kriz sayısını da arttırmıştır. Bireyler krizler ile karşılaştıkça deneyim kazanmakta, mesleklerini yaptıkları süre arttıkça yeni krizler ile tanışmakta, krizler hayatın her alanına girdikçe cinsiyet ayrımı gözetmeksizin geniş kitleleri etkilemektedir. Bu çalışma da demografik faktörlerin kriz yönetim becerilerine olan etkisi ele alınmıştır.

Çalışmanın analiz sonuçlarını incelendiğinde, katılımcıların cinsiyetine göre kriz yönetime beceri noktasında kadın turist rehberleri kriz anı ve kriz sonrası süreçleri yönetme noktasında erkek turist rehberlerinden daha başarılı olarak görülmüştür. Bu durum literatürde farklı çalışmalarda farklı sonuçlar doğurmuş olsa da uygulama ile de turizm alan yazını ile de örtüşmektedir. Uygulamada çıkan sonucun doğruluğu, bu araştırma yapılmadan 2 sene önce gerçekleşmiş olan 12 Ocak 2016 tarihli Sultanahmet intihar saldırısında görülmüştür. 10 kişinin ölüp 15 kişinin yaralandığı saldırıda canlı bombayı patlamadan kısa süre önce fark eden kadın turist rehberi Sibel Şatıroğlu patlamadan önce bölgede olan Alman turist gruplarına "Kaçın" diye bağırarak kısa sürede insanların kendilerini olaya hazırlayacak fırsatı sunmuştur (sabah.com.tr). Kadın turist rehberinin kriz anında bölgeden kaçmaya çalışmak yerine etraftaki turistleri korumaya yönelik bu davranışı bu araştırmada ortaya çıan sonucu da pekiştirici niteliktedir. Öte yandan turist rehberliği ve diğer turizm iş kollarında çalışan kadınları konu alan kimi çalışmaları incelediğimizde (Arslan ve Şimşek 2018; Demirkol vd., 2004; Yıldırım ve Özbek, 2019), taciz, zorlama gibi kriz durumları ile kadın çalışanların sıklıkla karşı karşıya geldikleri anlaşılmaktadır. Dolayısı ile erkek meslektaşlarına göre krizler ile daha çok karşılaştığı belirlenen kadın turist rehberlerinin krizleri yönetme becerilerinin erkeklere oranla daha yüksek olarak çıkması turizm alanında yapılan çalışma sonuçları ile uyum içerisindedir.

Çalışmada eğitim durumuna göre farklı kriz evrelerinde gösterilen davranışlarda bir farklılık belirlenmemiştir. Bu durum bakanlık kursu, iki yıllık, dört yıllık ya da yüksek lisans seviyesinde eğitim verilen turist rehberliği eğitim kurumlarının hiçbir eğitim kademesinde kriz yönetimi konusunda herhangi bir eğitim verilmediği ile açılanabilir. Turist rehberliği ders programları incelendiğinde dolaylı olarak kriz ile ilişkilendirilebilecek tek dersin bir kriz anı işlevini yerine getiren "ilk yardım" dersi olduğu görülmektedir (Yenipınar ve Kardaş, 2019). Ayrıca bu ders bütün turizm rehberliği programlarında da yer almamaktadır.

Demografik değerlendirmelerden sonuncusu olan çalışma kartına sahip olunan süre arttıkça krizi yönetebilme becerisinin de arttığı gözlenmektedir. Bu noktada literatürdeki diğer çalışmalar ile uyum söz konusudur. Burada özellikle kriz öncesi süreci yönetebilme yeteneklerinin çalışma süresi ile bağlantılı olarak artış içerisinde olması önemlidir. Daha önceden de belirtildiği gibi kriz yönetiminin en önemli kısmı kriz öncesi sürecin etkinliğidir. Bu dönemde yapılacak doğru hamleler ve etkin önlemler krizlerden kurtulmaya olanak sağlamakta veya daha az zarar görmeyi sağlayabilmektedir. Bu önlemlerin alınması ve hazırlıklar ise belirli bir deneyim sürecinden sonra meydana gelebilmektedir. 
Gerçekleştirilen bu çalışma neticesinde turist rehberlerinin krize süreçlerine hazırlık aşamasında eğitim seviyesinin herhangi bir fark yaratmaması önemli bir çıktı olarak görülebilir. Bu sebeple turizm rehberliği bölümlerinde farklı kriz türlerine karşı hazırlıklı olunabilmesi amacı ile kriz yönetiminin ders müfredatına eklenmesi önerilmektedir. Ayrıca Turist Rehberleri Birliği ve birliğe bağlı odalar da her sene olası krizler üzerine turist rehberlerinin daha hazırlıklı olabilmeleri adına kurs ve eğitim seminerleri düzenlemelidir. Ayrıca bu çalışma kapsamında meslekte geçirilen sürenin krizleri yönetebilme becerisine olumlu yönde etki ettiği de görülmüştür. Buradan hareketle meslek birlikleri özellikle mesleğe yeni başlayan turist rehberlerine yönelik ayrıca eğitim seminerleri ve bilgilendirme toplantıları düzenlemelidir.

$\mathrm{Bu}$ çalışmayı ilerletmek isteyen araştırmacılar, Çalışmaya dahil edilmemiş farklı demografik faktörleri irdeleyerek bu faktörlerin turist rehberlerinin krizleri yönetme becerileri ile olan ilişkilerini inceleyebilir. Böylece daha geniş çaplı bir kriz yönetim becerisine etki eden demografik faktör görüntüsü elde edilebilir.

\section{KAYNAKÇA}

Acar, V. (2014). Profesyonel Turist Rehberlerinin Liderlik Yönelimleri: Aydın Turist Rehberleri Odası'na Kayıtlı Olan Profesyonel Turist Rehberleri Örneği, Yayınlanmamış Yüksek Lisans Tezi, Adnan Menderes Üniversitesi, Aydın.

Akıncı, Z. (2010). Konaklama işletmelerinde Kriz Yönetimi: Alanya Bölgesindeki Konaklama İşletmelerinde Kriz Sürecinde Karşılaşılan Sorunların Tespit ve Çözümüne Yönelik Bir Araştırma, Yayınlanmamış Doktora Tezi, Süleyman Demirel Üniversitesi, Isparta.

Akoğlan Kozak, M. (2017). Rekreasyonel Liderlik ve Turist Rehberliği, Kavramlar ve Kurumlar Üzerinden Bir Analiz. Ankara: Detay Yayıncılık.

Aksu, A. ve Deveci, S. (2009). İlk Öğretim Okul Yönetimi Müdürlerinin Kriz Yönetimi Becerileri, e- Journal of New World Sciences Academy, 4(2): 448-464.

Arana, E.J. and Leon, C.J. (2008). The Impact of Terrorism on Tourism Demand, Annals of Tourism Research, 35(2): 299-315.

Arslan, A. ve Şimşek, G. (2018) Kadın Turist Rehberlerinin Yaşadıkları Mesleki Sorunlar: Aydın Turist Rehberleri Örneği, Journal of Travel and Tourism Research, 13 :23-49.

Aşık, M. (2016). Turizm İşletmelerinde Kriz ve Kriz Yönetimi, Bodrum Bölgesindeki Beş Yıldızı Otel İşletmelerine Yönelik Bir Araştırma, Yayınlanmamış Yüksek Lisans Tezi, Namık Kemal Üniversitesi, Tekirdağ.

Coombs, W. (2006). Code Red in the Boardroom, Crisis Management as Organizational DNA. London: Praeger

Çakmak, T.F. (2019a). Turizm Endüstrisinde Bütüncül Yaklaşımla Kriz Yönetimi ve Örnek Olaylar. Ankara: Detay Yayıncilık.

Çakmak, T. F. (2019b). Yasa Dışı Rehberlik Faaliyetlerinin Denetlenmesi: İstanbul Rehberler Odası Örneği, Turizm Akademik Dergisi, 6(2): 31-41.

Çelikkan, O, (2012). Uluslararası Kriz Yönetimi, (Editör) Erol, S. M. Efegil, Krizler ve Kriz Yönetimi içinde (ss.2-19), Ankara, Barış Yayınları.

Çetin, G. ve Kızılırmak, İ. (2012). Türk Turizminde Kokartlı Turist Rehberlerinin Mevcut Durumunun Analizi, Afyon Kocatepe Üniversitesi İ̈BF Dergisi, 14(2): 307-318. 
Çiftçi, G. (2015). Turizm İşletmelerinde Kriz Yönetimi Uygulamalarının Örgütsel Öğrenme ve İşletme Performansı Açısından Ampirik Olarak Analizi, Yayınlanmamış Doktora Tezi, Namık Kemal Üniversitesi, Tekirdağ.

Demirkol, Ş. Fidan, F. ve Pelit, E. (2004). “Turizm Sektöründeki Bayan İşgörenlerin Karşılaştıkları Sorunlar ve Otel İşletmelerinde Bir Uygulama", Abant İzzet Baysal Üniversitesi Sosyal Bilimler Enstitüsü Dergisi, 1(8): 71-88.

Drakos K. and Kutan, A.M. (2003). Regional Effects of Terrorism on Tourism in Three Mediterranean Countries, Journal of Conflict Resolution, 47 (5): 621-641.

Dinçer, Ö. (2013). Stratejik Yönetim ve İşletme Politikası. (9. Basım), İstanbul: Beta Yayınları.

Fletcher, J. and Morakabati, Y. (2008). Tourism Activity, Terrorism and Political Instability within the Commonwealth: The cases of Fiji and Kenya, International Journal of Tourism Research, 10(6): 537-556.

Güzel, Ö. F. ve Köroğlu, Ö. (2014). Turist Rehberlerinin Liderlik ve Aracilık Rollerinin Tur Deneyimine Etkisi: Doğa Turları Üzerine Bir Araştırma, Gaziantep University Journal of Social Sciences, 13(4): 939-960.

Karacaoğlu, S. ve Serti, A. N. (2018). Turist Rehberleri Meslek Sorunları Üzerine Bir Araştırma: Kapadokya Örneği. Journal of Tourism and Gastronomy Studies, 6(3): 81-90.

Karamustafa, K. ve Çeşmeci, N. (2006). Paket Tur Operasyonunda Turist Rehberlerinin Karşılaştıkları Yönetsel Sorunlar Üzerine Bir Araştırma, Anatolia: Turizm Araştırmaları Dergisi, 17(1): 70-85.

Kaya, A., Yetgin Akgün, D. ve Çiftci, G. (2020). Krizlerin Turist Rehberliği Öğrencilerinin Mesleki Tutumları ile İlişkisi, Türk Turizm Araştırmaları Dergisi, 4(3): 2907-2923.

Kılıçdere, S. (2017). Seyahat Acentalarında Kriz Yönetimi Kapsamında 2016 Turizm Sezonunun Değerlendirilmesi, Yayınlanmamış Yüksek Lisans Tezi, Adnan Menderes Üniversitesi, Aydın.

Kuklan, H, (1988). Crisis Confrontation in International Management: Consequences and Coping Actions, Management International Review, 28(3): 21-30.

Kongar, E. (2012). Küresel Terör ve Türkiye. (12. Basım), İstanbul: Remzi Kitapevi.

Korstanje, M. E. and Clayton, A. (2012). Tourism and terrorism: conflicts and commonalities, Worldwide Hospitality and Tourism Themes, 4(1): 8 - 25.

Küçükaltan, D. ve Çiftçi, G. (2016). Turizm İşletmelerinde Kriz Yönetimi, (Editör) Akova, O. Kızılırmak, İ. Tanrıverdi, H.: Turizm İşletmeciliğgi içinde (ss.251-272) Ankara: Detay Yayıncılık.

Küçükaltan, D. (2012). Terörizmin Hedefindeki Sektör: Turizm (Kronolojik bir Yaklaşım). Ankara: Detay Yayıncilık.

Lind, C. M. and Lind I. Y. (1986). Visitors as Victims: Crimes Against Tourists in Hawaii. Annals of Tourism Research, 13: 167-191.

Maya, İ. (2014). Kamu İlkokullarında Yöneticilerin Sergiledikleri Kriz Yönetimi Beceri Düzeylerine İlişkin Öğretmen Görüşleri, Yönetim Bilimleri Dergisi, 12 (23): 209-235.

Okumuş, F. (2003). İşletmelerde Kriz Yönetimi ve Krizlerin İşletmeler Üzerinde Olası Etkileri, İktisadi ve İdari Bilimler Dergisi, 17(1): 203-212.

Örnek, A. ve Aydın, Ş. (2008). Kriz ve Stres Yönetimi. Ankara: Detay Yayıncılık. 
Öztürk, A. (2011). Kriz Sosyolojisi. İstanbul: Doğu Kitabevi.

Pearson, M., Misra, S. K., Clair, J. A. and Mitroff, I (1997). Managing the Unthinkable, Organizational Dynamics 26(2): 51-64.

Pizam, A. and Smith, G. (2000). Tourism and Terrorism: A Quantitative Analysis of Major Terrorist Acts and Their Impact on Tourism Destinations, Tourism Economics, 6(2): 123-138.

Pizam, A. (1999). A Comprehensive Approach to Classifying Acts of Crime and Violence at Tourism Destinations, Journal of Travel Research, 38, 5-12.

Richter, L. (1983). Tourism politics and political science: A case of not so benign neglect, Annals of Tourism Research, 1: 313-335.

Ritchie, W. B. and Campiranon, K. (2014). Major Themes and Perspectives, (Editör) Ritchie, W. B., Campiranon, K., Tourism Crisis and Disaster Management in The Asia. UK, Cabi Press

Sabah.com, Sultanahmet'te Bomba Dehşeti, [ https://www.sabah.com.tr/gundem/2016/01/13/sultanahmette-canli-bomba-dehseti ] adresinden 27.03.2020 tarihinde alınmıştır.

Saruhan, C. Ş. ve Yıldız L. M. (2013). Çă̆daş Yönetim Bilimi. İstanbul: Beta Yayınları.

Seddighi, H. R., Theocharous, A. L. and Nuttall, M.W. (2002). Political Instability and Tourism: An Empirical Study with Special Reference to the Microstate of Cyprus, International Journal of Hospitality \& Tourism Administration, 3(1): 61-83.

Smeral, E. (2009). The Impact of the Financial and Economic Crisis on European Tourism, Journal of Travel Research 48(1): 3-13.

Spillan, J. E. (2003). An Exploratory Model for Evaluating Crisis Events and Managers' Concerns in Non-profit Organizations, Journal of Contingencies and Crisis Management, 11(4): 160-169

Soysal, A., Pakoy, H. M.ve Özçalıcı, M. (2011). Kriz Dönemlerinde Liderlik Yetneğinin Bazı Demografik Değişkenler Açısından Değerlendirilmesi, Journal of Entrepreneurship and Development, 6(1): 222-248.

Sönmez, S. F. Apostolopulos, Y. and Tarlow, P. (1999). Tourism in Crisis: Managing the Effects of Terrorism, Journal of Travel Research, 38: 13-18.

Sönmez, S. F., and Graefe, A. R. (1998). Influence of Terrorism Risk on Foreign Tourism Decision, Annals of Tourism Research, 25(1): 112-144.

Stafford, G. Y. (2002). Crisis Management and Recovery: How Washington D.C. Hotels Responded to Terrorism? Cornell Hotel and Restaurant, 43(5): 27-40.

Şahin, S. (2010). Kriz ve Kriz Yönetimi Kapsamında Küçülme: Konaklama İşletmelerinde Örnek Bir Uygulama, Yayınlanmamış Yüksek Lisans Tezi, Balıkesir Üniversitesi, Balıkesir.

Tekin, M. ve Zerenler, M. (2005). Krizi Yönetebilmenin Sırları. Konya: Çizgi Kitabevi.

Thom, R. (2001). Bilim Kendi Krizleri Aracılığı ile İlerler, Cogito, 27: 144-150.

Tutar, H. (2000). Kriz ve Stres Ortamında Yönetim. İstanbul: Hayat Yayınları.

Türkmen, M. (2017). Turist Rehberlerinin Liderlik Yönelimlerinin Belirlenmesine Yönelik Bir Araştırma, Gaziantep University Journal of Social Sciences, 16 (3): 913-927.

Tüz, M. (2008). Kriz Yönetimi, (4. Basım) Bursa: Şah-Mat Matbaa. 
Ulutaş, S. (2010). Kriz Yönetimi ve Dönüşümcü Liderlik, Yayınlanmamış Yüksek Lisans Tezi, Dokuz Eylül Üniversitesi, İzmir.

Vivero, R. L. (2008). Terrorism and international Tourism: New Evidence, Defense and Peace Economics, 19(2): 169-188.

Wong, J.Y. and Lee, W.H. (2012). Leadership Through Service: An Exploratory Study of the Leadership Styles of Tour Leaders, Tourism Management 33: 1112-1121.

Yazıcığlu, Y. ve Erdoğan S. (2004). Spss Uygulamalı Bilimsel Araştırma Yöntemleri. Ankara: Detay Yayıncilik.

Yenipınar, U. Bak, E. ve Çapar, G. (2014). Turist Rehberliği Meslek Kanununun, Meslek Örgütleri ve Öğretim Elemanlarının Bakış Açısı ile Değerlendirilmesi, Çă̆ Üniversitesi Sosyal Bilimler Dergisi, 11(2), 86-11.

Yenipınar, U. ve Kardaş, K. (2019). Turist Rehberliği Bölümleri Müfredat Geliştirme Önerisi, Journal of Travel and Tourism Research, 15:1-26.

Yetgin, D., Yılmaz A. ve Çiftci, G. (2018). Krizlerin Turist Rehberliği Öğrencilerinin Kariyer Planlamasındaki Etkisi, Journal of Tourism and Gastronomy Studies, 6(3), 195-214.

Yıldırım, G. ve Özbek, Ö. (2019). Profesyonel Turist Rehberlerine Yönelik Cinsel Taciz ile İlgili Bir Araştırma. Turist Rehberliği Dergisi, 2 (2), 72-87. 